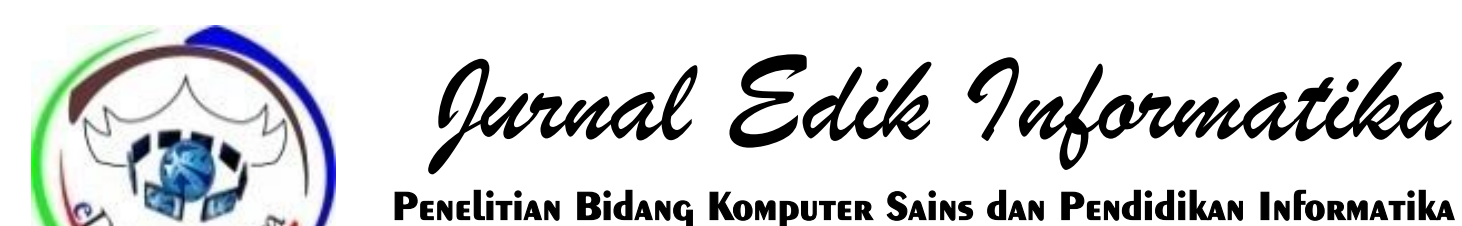

Website: ejournal.stkip-pgri-sumbar.ac.id/index.php/eDikInformatika

\title{
PENERAPAN APLIKASI QUICK RESPONSE DALAM MELAYANI PENGADUAN MASYARAKAT BERBASIS WEB DAN SMS GATEWAY
}

\author{
Ganda Yoga Swara \\ Institut Teknologi Padang \\ gandayogaswara@itp.ac.id
}

\begin{tabular}{l} 
INFO ARTIKEL \\
\hline Diterima: \\
04 Mei 2020 \\
Direview: \\
05 Mei 2020 \\
Disetujui: \\
19 Mei 2020 \\
\hline Keywords: \\
\hline Web, Sms Gateway, \\
Php, MySQL, Gammu
\end{tabular}

\begin{abstract}
Quick Response application is an application designed to meet the needs of the community. This application is a forum for the public to convey to the relevant Regional Government. Types of complaints that the public can convey are complaints, questions, information and suggestions / proposals related to the topic of the complaint, namely about education, agriculture, health, population, food crop agriculture, road infrastructure, tourism, youth, sports, disaster management, and trade and market. The application designed in this research is web based and SMS Gateway. In its design, this website is made using the PHP programming language and also uses the MYSQL database. For SMS Gateway, it was designed using Gammu application. By using the web, people can send their complaints online. Even the public can also ask for their complaints with the SMS service. With this application, it is also expected to be able to facilitate the local government, as well as related parties involved and provide responses from public complaints that can be accounted for.
\end{abstract}

\section{PENDAHULUAN}

Perkembangan

teknologi

khususnya teknologi jaringan internet pada saat ini sangat pesat, dunia kini memasuki era globalisasi di mana teknologi jaringan internet memegang peranan penting dalam kehidupan manusia. Dengan adanya internet dapat mempermudah dalam berbagi informasi, khususnya pengguna website. Website memiliki peran penting dalam berbagi informasi bagi instansi pemerintahan, baik pemerintah daerah maupun pusat.
Pada dasarnya, kepala daerah memiliki tugas dan wewenang dalam memimpin dan mewujudkan keadilan serta kesejahteraan rakyat dengan dibantu oleh pihak dinas terkait yang memiliki fungsi dan kinerja masing-masing. Namun, permasalahan untuk mewujudkanya adalah masyarakat memiliki kendala untuk berperan dalam menyampaikan aspirasi mereka, di mana masyarakat harus datang langsung dan bertatap muka dengan pihak terkait untuk membahas pengaduan mereka yang tentunya memiliki beberapa faktor 
penghalang. Salah satu faktornya adalah waktu. Jarak alamat rumah dengan kantor dinas juga menjadi faktor penghalang mereka serta luasnya daerah kabupaten tentunya tidak semua yang dapat tersentuh oleh tangan pemerintah. Dalam proses pengaduan masyarakat juga menjadi kendala, masyarakat harus menunggu waktu yang lama untuk menunggu pengaduan mereka diproses. Selain itu, kurang terjaminnya keamanan berkas atau laporan dari pengaduan masyarakat juga menjadi kendala (Wiratmo, 2017).

Dengan permasalahan tersebut, penulis mencoba untuk menuangkan ide dengan pemanfaatan layanan elektronik online berbasis web dan SMS gateway. Pengaduan dari masyarakat dapat langsung diproses oleh pihak dinas yang nantinya akan dikelola oleh pihak kabupaten. Proses pengaduan dapat dengan cepat ditanggapi (quick response). Untuk selanjutya disampaikan kembali kepada masyarakat yang memberikan pengaduan.

Masyarakat juga dapat menyampaikan aspirasi mereka melalui SMS gateway. Terutama bagi daerah yang kurang tersentuh jaringan internet. Dengan layanan SMS gateway ini, masyarakat cukup mengirim SMS kepada dinas terkait dengan format yang telah ditentukan. Selanjutnya masyarakat dapat menunggu waktu proses dari pengaduan tersebut. Pengaduan akan ditanggapi oleh pihak terkait dalam waktu yang lebih cepat jika dibandingkan dengan pengaduan secara manual.

\section{METODE}

Metode yang digunakan dalam pengumpulan data ini adalah metode penelitian lapangan (Field Research) dengan teknik:

a. Wawancara (Interview)

Wawancara yaitu pengumpulan data dengan cara melakukan tanya jawab terhadap beberapa dinas/kantor pemerintahan.

b. Pengamatan (Observation)

Tinjauan dan pengamatan secara langsung dilakukan untuk melengkapi data.

c. Penelitian Kepustakaan (Library Research)

Penelitian kepustakaan yaitu dengan mempelajari literatur-literatur yang ada, berkaitan dengan permasalahan yang dibahas.

Dalam pengembagang sistem, model yang digunakan yaitu model Waterfall, dengan tahapan seperti terlihat pada Gambar 1.

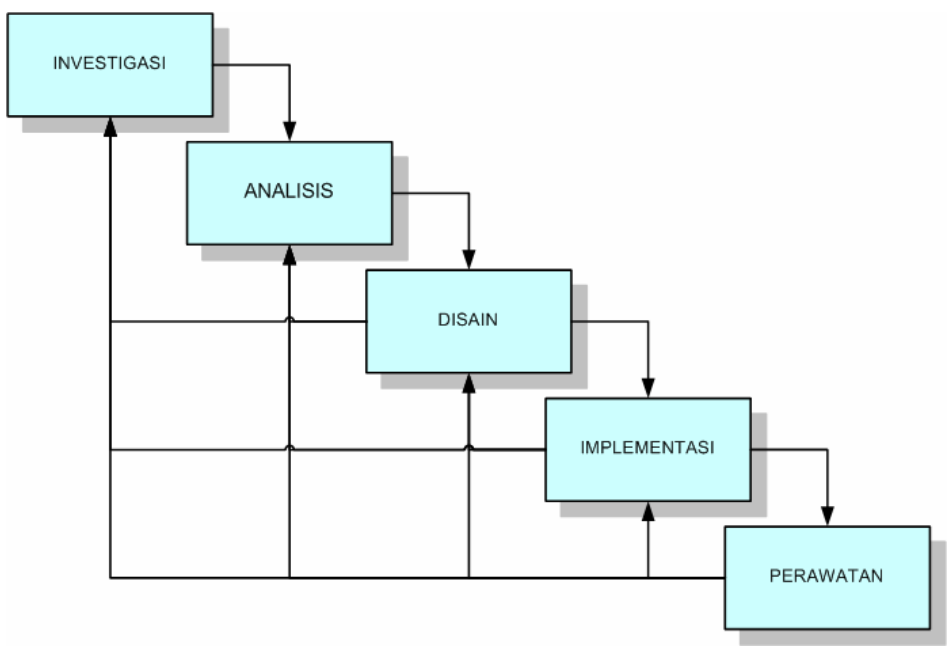

Gambar 1. Metode Waterfall 


\section{Investigasi}

Dalam permasalahan ini, ada 2 kebutuhan dalam menyelesaikan permasalahan tersebut. Yaitu website dan sms gateway. Istilah gateway dapat diartikan sebagai pintu gerbang. Namun pada dunia komputer, gateway dapat diartikan sebagai jembatan penghubung antara satu sistem dengan sistem yang lain, sehingga dapat terjadi pertukaran data antar sistem tersebut. Dengan demikian, SMS gateway dapat diartikan sebagai penghubung untuk lalu lintas data-data SMS (Siregar, 2017).

\section{Analisis}

Dalam perencanaan, secara garis besar bisa digambarkan dalam Context Diagram. Context diagram pada Gambar 2 menjelaskan bahwa masyarakat bisa mengirimkan pengaduan ke sistem, baik melalui web maupun SMS gateway. Kemudian sistem akan memberikan jawaban dari pengaduan tersebut.

\section{Perancangan}

Dalam tahap perancangan ini, perancangan entity relationship diagram
(ERD) menjadi gambaran dari struktur database yang akan dikembangkan (Swara, 2017). Database yang digunakan adalah database MySQL (Yanto, 2016)

\section{Implementasi}

Tahapan di mana seluruh desain diubah menjadi kode kode program. Kode program yang dihasilkan masih berupa modul-modul yang akan diintegrasikan menjadi sistem yang lengkap.

\section{Perawatan}

Pemeliharaan suatu software sangat diperlukan, termasuk di dalamnya adalah pengembangan, karena software yang dibuat tidak selamanya hanya seperti itu. Ketika dijalankan mungkin saja masih ada errors kecil yang tidak ditemukan sebelumnya, atau ada penambahan fiturfitur yang belum ada pada software tersebut. Pengembangan diperlukan ketika adanya perubahan dari eksternal seperti ketika ada pergantian sistem operasi, atau perangkat lainnya.

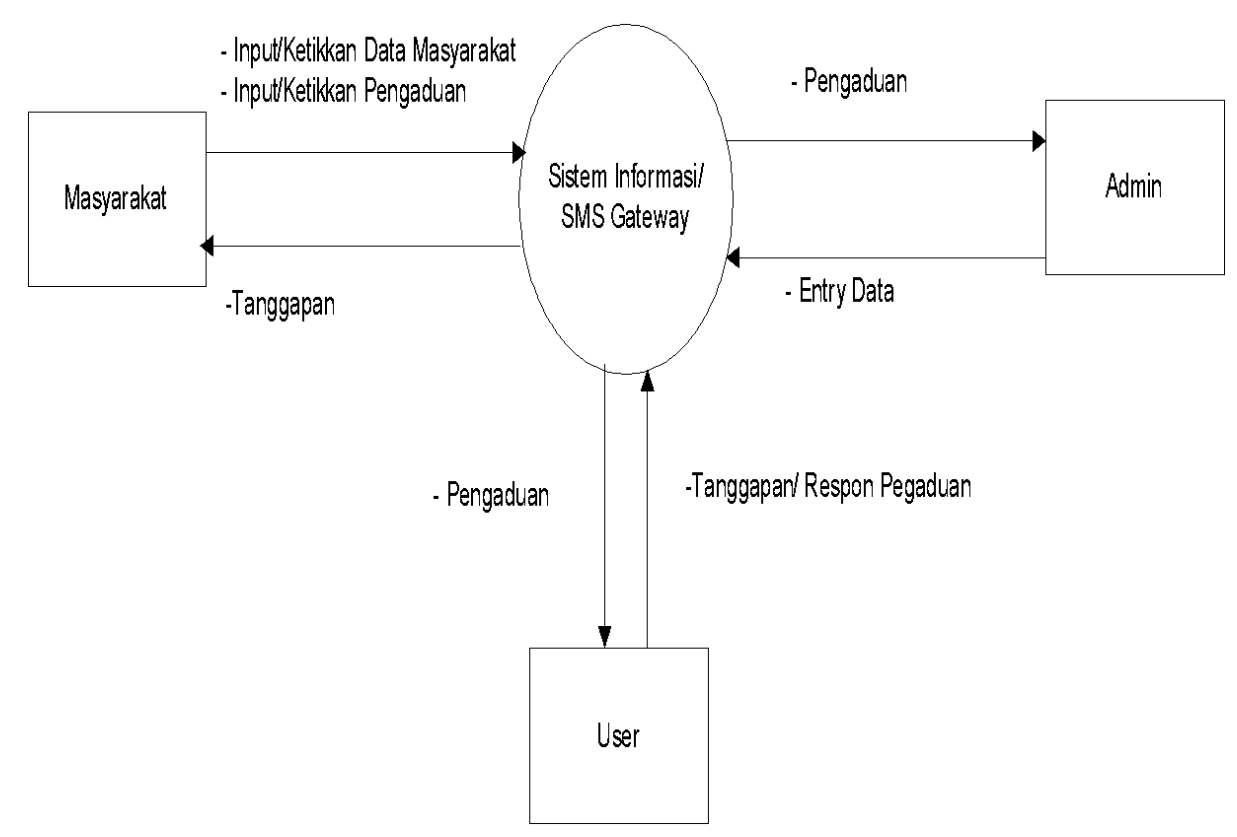

Gambar 2. Context Diagram 


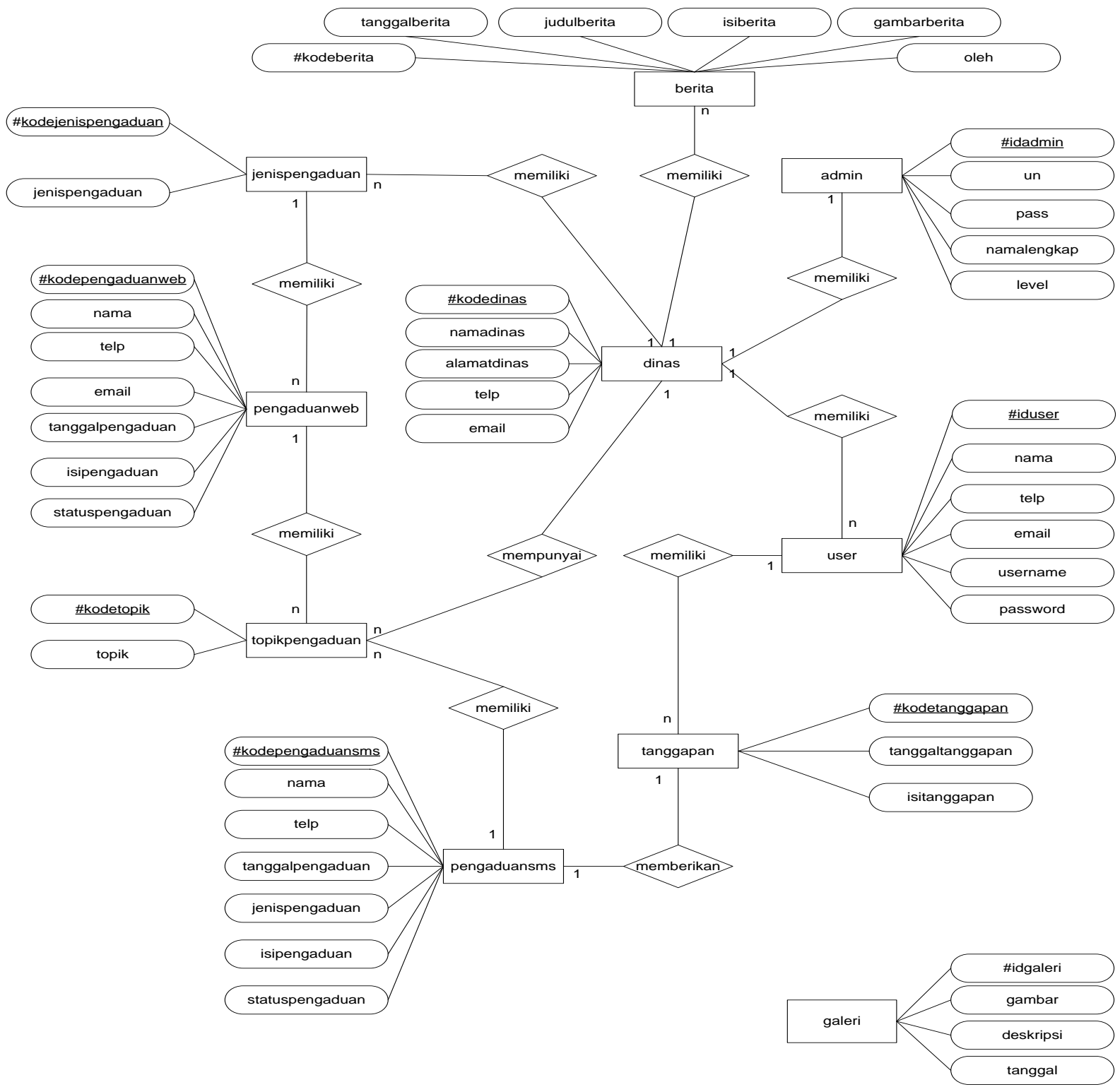

Gambar 3. Entity Relationship Diagram

\section{HASIL DAN PEMBAHASAN}

Aplikasi quick response yang dikembangkan terdiri dari beberapa menu atau halaman yang dapat diakses oleh pengguna.

\section{Halaman Utama}

Merupakan halaman yang pertama kali muncul ketika sistem diakses oleh pengguna. Pada halaman utama (Gambar 4) menampilkan secara keseluruhan menu-menu yang terdapat pada program aplikasi quick response dalam melayani pengaduan masyarakat berbasis web dan SMS gateway, diantaranya adalah menu home, dan menu pengaduan.

Menu home berfungsi untuk mengarahkan masyarakat pada halaman utama, sedangkan menu pengaduan, berfungsi untuk mengarahkan masyarakat pada halaman untuk input pengaduan mereka serta halaman untuk petunjuk SMS. 

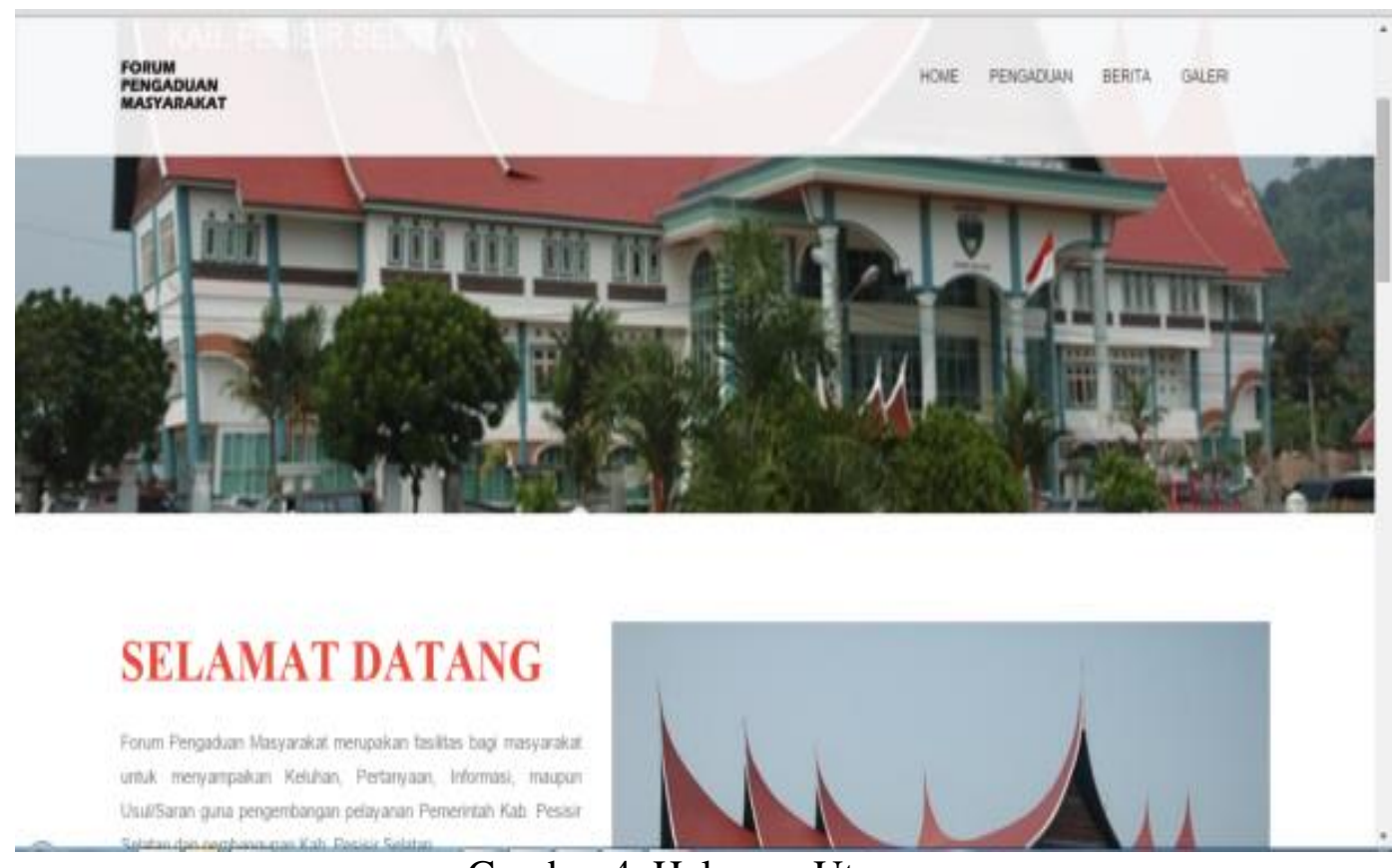

Gambar 4. Halaman Utama

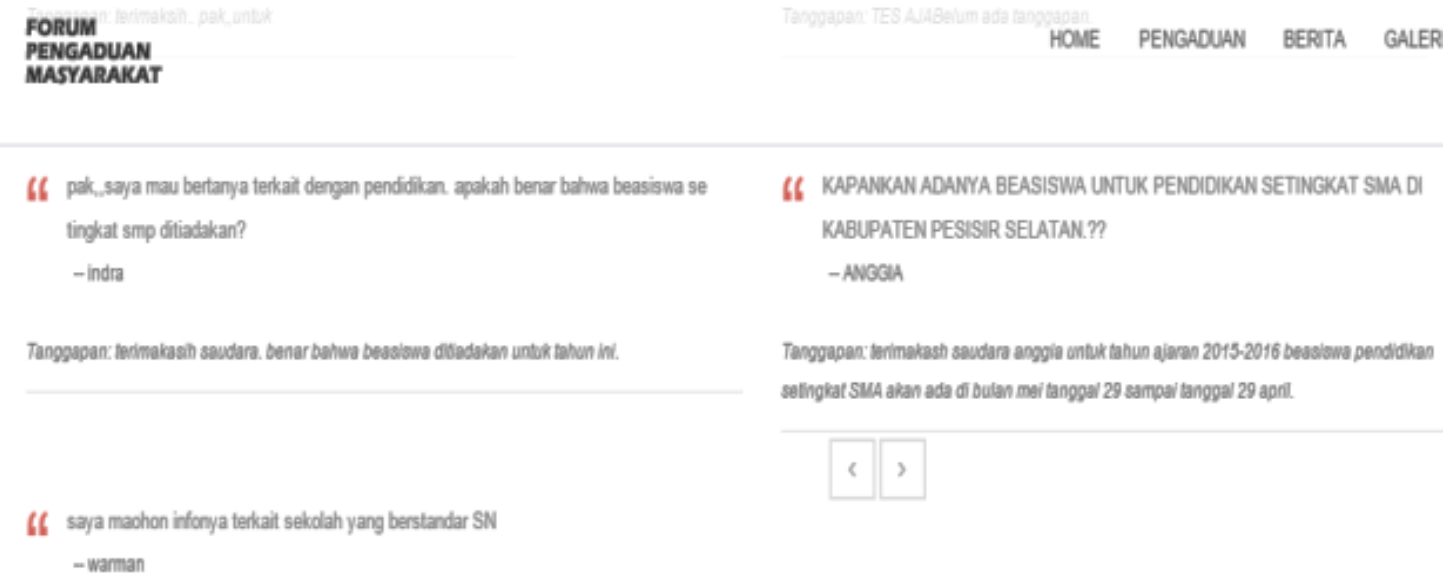

Gambar 5. Halaman Tanggapan Pengaduan

\section{Halaman Pengaduan}

Halaman pengaduan dibagi menjadi 3 buah segmen yang berbeda yang saling berhubungan dalam pengajuan pengaduan. Segmen tersebut adalah: Tanggapan Pengaduan, Input Pengaduan dan Petunjuk Pengaduan.

Pada segmen Tanggapan Pengaduan yang terdapat pada Gambar 5, Bisa terlihat bahwasanya pada halaman

tersebut terdapat informasi atau jawaban dan penjelasan mengenai pengaduan yang telah dilaporkan oleh masyarakat.

Sementara jika kita ingin membuat atau melaporkan sebuah pengaduan maka bisa langsung mengisi pengaduan pada form Input Pengaduan seperti yang terdapat pada Gambar 6. 


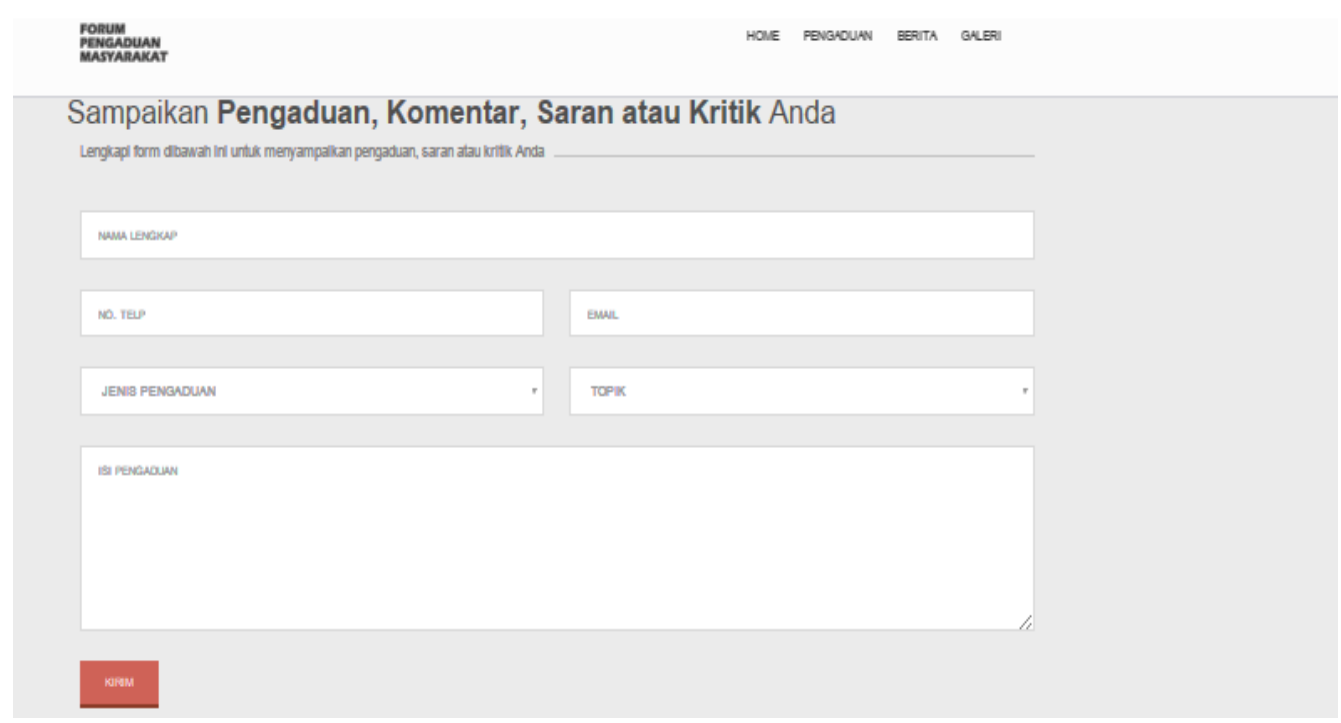

Gambar 6. Halaman Input Pengaduan

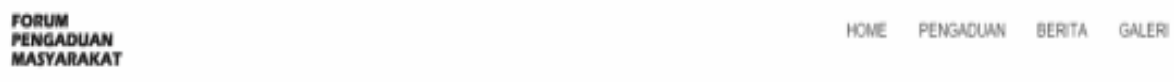

\section{Sampaikan Melalui SMS}

ANDA JUGA DAPAT MENYAMPAIKANNYA MELALUI SMS DENGAN FORMAT:

JENIS ASPIRASIETOPIK\#NAMA LENGKAPHISI ASPIRASI

CONTOH:

KELUHAN\#PRASARANA JALANHJOKO SUSILO\#TOLONG

PERHATIKAN KONDISI JALAN, KARENA BANYAK LUBANG

Silahkan lihat keterangan disamping ini untuk topik dan jenis aspirasi

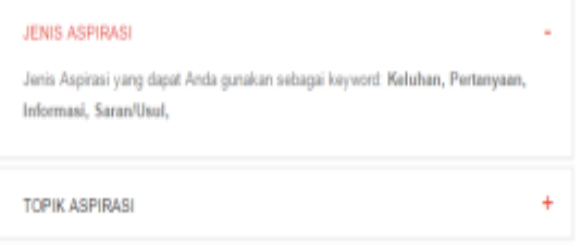

Gambar 7. Halaman Petunjuk SMS

Pada Gambar 6 terlihat, bagi yang ingin membuat pengaduan maka harus mencantumkan beberapa informasi seperti: Nama, No HP, Email, Jenis Pengaduan serta isi pengaduan dan kemudian mengklik button "Kirim" untuk mengirimkan pengaduan. Seterusnya akan terlihat segmen petunjuk dalam pelayanan untuk pengaduan, baik melalui web maupun SMS gateway seperti yang terlihat pada Gambar 7.

\section{Halaman Login}

Halaman login (Gambar 8) merupakan halaman gerbang pemisah sebelum memasuki menu apa saja yang dapat diakses oleh admin dan user. Dengan menginputkan username dan password yang telah ada pada sistem, maka admin dan user dapat mengakses menunya masing-masing. 


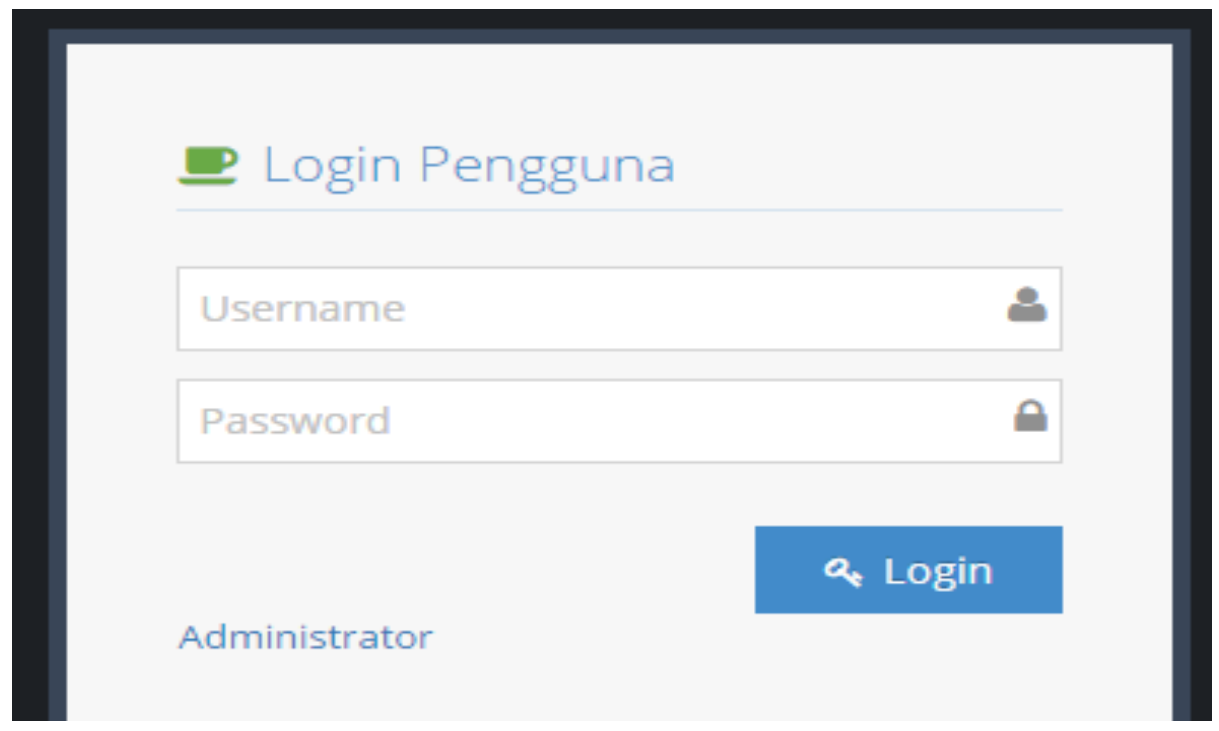

Gambar 8. Halaman Login

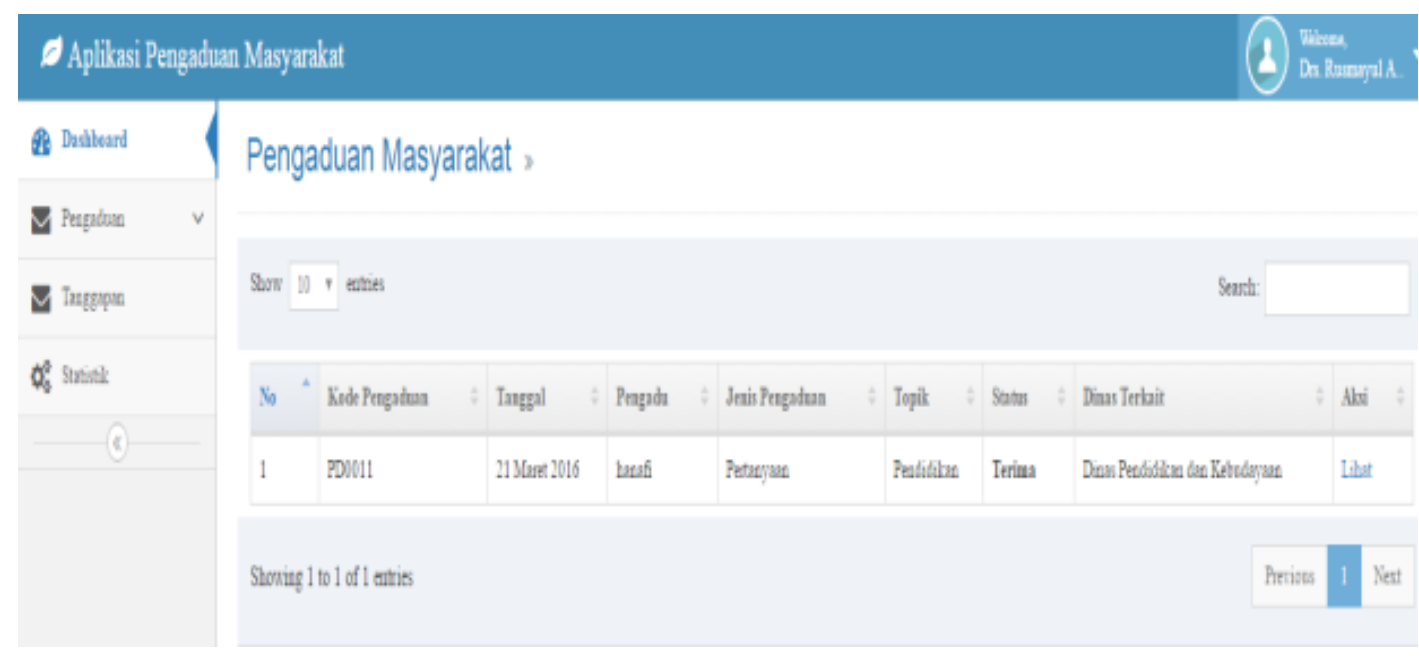

Gambar 9. Halaman Pengaduan Via Website

\section{Halaman Pengaduan Via Website}

Setelah login ke dalam sistem, maka admin bisa melakukan pengelolaan terhadap sistem, termasuk melakukan balasan terhadap pengaduan yang masuk ke dalam sistem. Untuk memberikan tanggapan pengaduan melalui halaman pengaduan via website, maka yang dapat dilakukan adalah lihat dan balas pengaduan (Gambar 9).

\section{Halaman Pengaduan Via SMS}

Dan hal yang sama juga berlaku untuk pemberian tanggapan terhadap pengaduan via SMS yang dapat dilakukan adalah lihat pesan yang masuk dan berikan tanggapan terhadap pesan pengaduan yang masuk melalui SMS (Gambar 10). Pengaduan yang masuk via sms juga bisa dilihat melalui website seperti pada Gambar 11. 


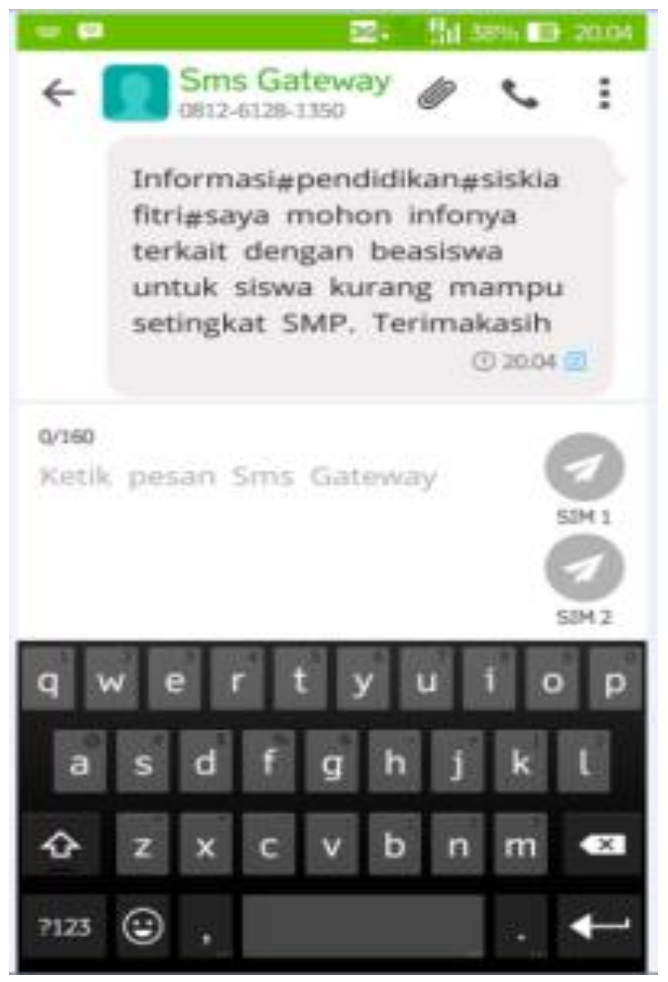

Gambar 10. Pengaduan dari HP masyarakat

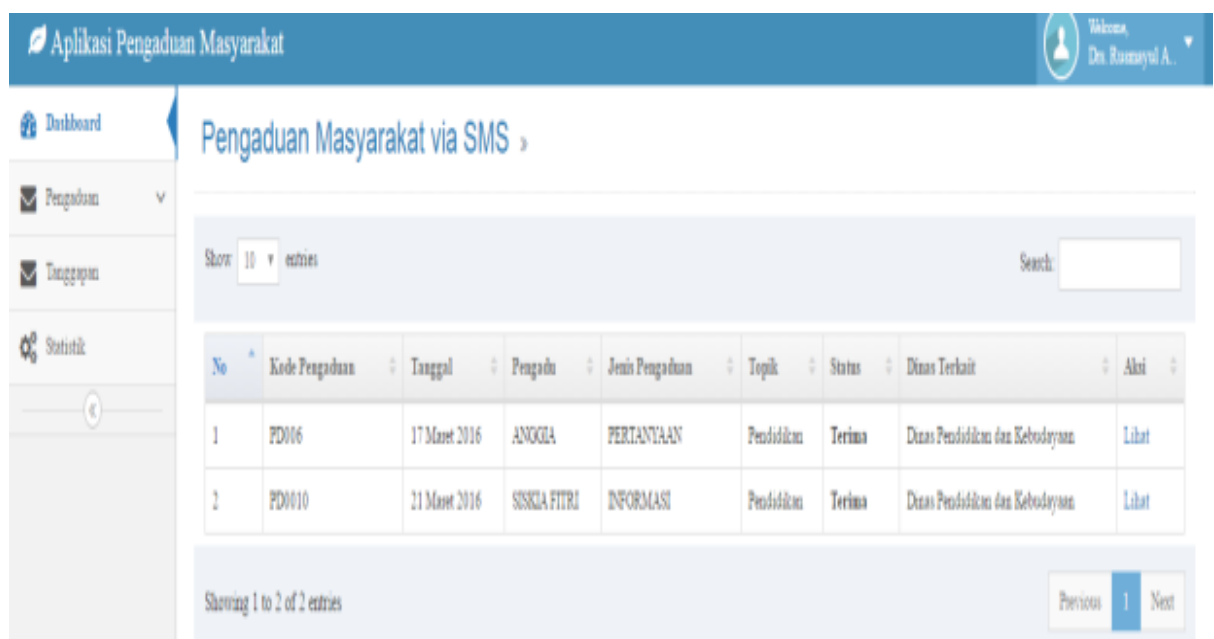

Gambar 11. Halaman Pesan Masuk ke Sistem

Cara kerja pemberian tanggapan SMS melalui halaman website sama dengan memberikan tanggapan pada pengaduan yang masuk melalui website secara langsung. Setelah tanggapan diberi komentar atau dibalas maka secara otomatis pesan tersebut akan terkirim melalui No $\mathrm{Hp}$ masyarakat yang memberikan pengaduan. Gambar 12 memperlihatkan bentuk SMS tanggapan (response) yang masuk ke dalam No HP pengadu. 


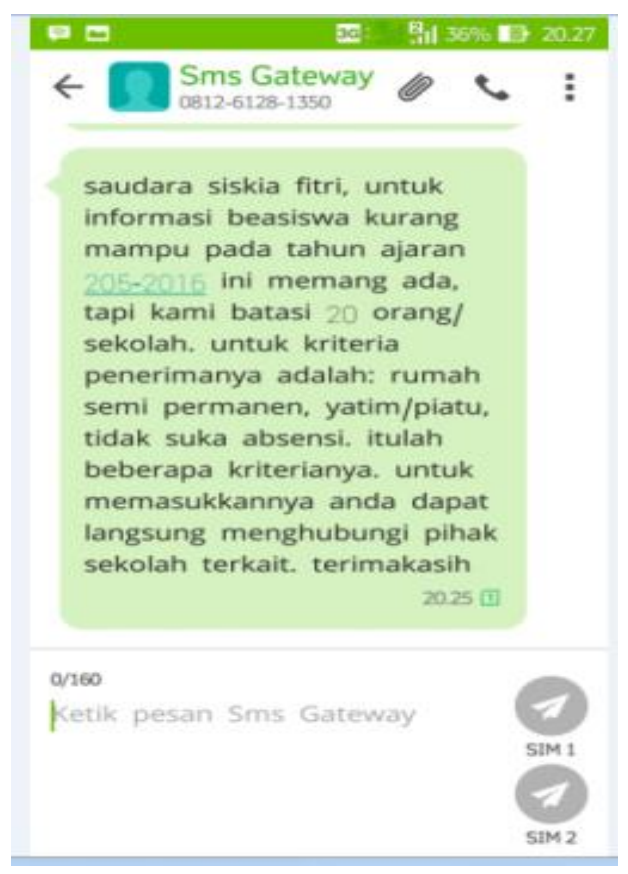

Gambar 12. Halaman Tanggapan ke HP masyarakat

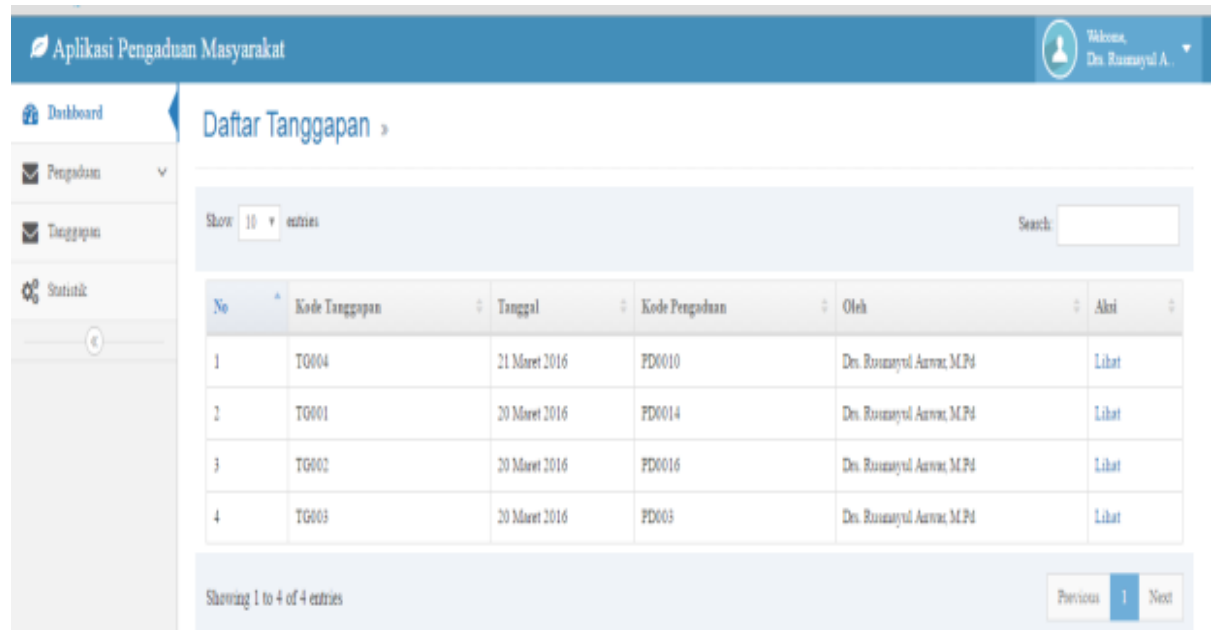

Gambar 13. Halaman Tanggapan

\section{Halaman Tanggapan}

Halaman Tanggapan (Gambar 13) adalah halaman untuk menampilkan pesan yang sudah dibalas, baik via website maupun via SMS.

\section{KESIMPULAN DAN SARAN}

Berdasarkan pembahasan yang telah dilakukan, aplikasi web ini memiliki beberapa menu. Akan tetapi menitik beratkan kepada menu pengaduan. Pengaduan bisa dilakukan melalui website dan SMS. Selain itu dengan penerapan aplikasi Web dan SMS gateway ini dapat mempermudah pihak terkait dalam melayani, menampung dan menanggapi pengaduan masyarakat.

Setelah menarik kesimpulan dari analisis yang dibuat, maka saran yang berkaitan dengan sistem yang dibangun ini, yaitu: dalam implementasi SMS gateway, diharapkan dapat memicu bagi 
peneliti yang lain untuk terus mengembangkan dan menyempurnakan sistem ini, seperti layanan aplikasi ini juga dapat diakses pada Android seperti yang lebih umum dikenal masyarakat sekarang ini.

\section{DAFTAR PUSTAKA}

Fitriandi, Afrizal, Endah, K., \& Herri G. (2016). Rancang Bangun Alat Monitoring Arus dan Tegangan Berbasis Mikrokontroler dengan SMS Gateway. Jurnal Rekayasa dan Teknologi Elektro 10(2): 8798.

Liu, Jianqi, et al. (2017). A scalable and quick-response software defined vehicular network assisted by mobile edge computing. IEEE Communications Magazine. 55(7): 94-100.

Sari, Dian, P., Ochi M. F., \& Arie S. P. (2018). Perancangan Sistem
Informasi SDM Berprestasi pada SD Global Surya. Prosiding Seminar Nasional Darmajaya. 1(1).

Siregar, Iqbal, K., \& Faisal T. (2017). Perancangan Aplikasi Sms Alert Berbasis Web. JIMP-Jurnal Informatika Merdeka Pasuruan 2 (2).

Swara G.Y., \& Yunes P.(2016). Rekayasa perangkat lunak pemesanan tiket bioskop berbasis web. Jurnal TeknoIf .4(2).

Wiratmo, Liliek. B., Noor I, \& Kuwatono. (2017). Website Pemerintah Daerah sebagai Sarana Online Public Relations. Jurnal ASPIKOM. 3(2): 326-339.

Yanto, Robi. Manajemen Basis Data Menggunakan MySQL. Deepublish, 2016. 